\title{
Oral Defense: How Oral Rehydration Solutions Revolutionized the Treatment of Toxigenic Diarrhea
}

\author{
Jonathan D. Kaunitz ${ }^{1}$ (D)
}

Published online: 3 January 2020

(c) This is a U.S. Government work and not under copyright protection in the US; foreign copyright protection may apply 2020

Oral rehydration solutions (ORS) arguably represent the most cost-effective medical treatment known, wherein a few pennies worth of sugar, salt, and clean water can reduce the mortality of toxigenic secretory diarrhea 50 -fold or more [1]. The story of ORS development predictably has many twists, paradigm shifts, intrigues, and at least one Nobel Prize accumulated along the way, encompassing fields as diverse as epidemiology, microbiology, intestinal physiology, and public health, and advancing science among many disciplines. Unlike most medical interventions, there has been scant commercial involvement, with dissemination of ORS dependent on global institutions with public health outreach such as the United Nations Childrens' Emergency Fund (UNICEF) and the World Health Organization. All of these elements summate into a fascinating story that I will describe in modest detail prior to introducing the key articles that review essential aspects of ORS development and dissemination.

Cholera is believed to have originated in the Ganges delta of India most likely in antiquity [2, 3]. The first Englishlanguage accounts awaited colonization by European settlers and the spread of the disease out of the Indian subcontinent, with a series of pandemics starting in 1817 and lasting to the present. The major paradigm shifts include the pioneering studies of John Snow starting in 1849 [4, 5], considered the first true epidemiologic analysis of any disease. Dr. Snow, through careful mapping of the 1854 London pandemic, discovered that most of the victims clustered around one well, suggesting a waterborne source of the disease [4]. In a well-publicized experiment, he reported that removal of the pump handle decreased the incidence of cholera in the target area. In the same year, the Italian scientist Filippo

Jonathan D. Kaunitz

jake@ucla.edu

1 Medical Service, West Los Angeles VAMC and Departments of Medicine and Surgery, David Geffen School of Medicine at UCLA, Los Angeles, CA, USA
Pacini identified comma-shaped organisms termed vibrios in the gastrointestinal contents of corpses of cholera victims, hypothesizing that these organisms were responsible for the copious intestinal fluid secretion characteristic of the disease, even proposing intravenous $\mathrm{NaCl}$ as a remedy [2, $6,7]$. These data unfortunately were not powerful enough to dislodge the prevailing "miasma" theory that cholera was transmitted by the foul air associated with poverty, overcrowding, and poor sanitation championed in particular by Max Joseph von Pettenkofer, an aristocratic Bavarian chemist and hygienist. Tragically, Pacini's data were overlooked for 30 years, until the eminent microbiologist Robert Koch was able to identify vibrio organisms in the intestines of those who succumbed to the disease and grow them in liquid culture $[2,8]$.

The first published description of fluid resuscitation for cholera was published in 1831 by William B. O'Shaughnessy, who hypothesized that “...universal stagnation of the venous system, and rapid cessation of the arterialization of the blood, are the earliest, as well as the most characteristic effects." He proposed intravenous salt solutions, but not for their volume-expanding effects but for their oxygen content, recommending $\mathrm{KNO}_{3}$ or $\mathrm{KClO}_{3}$ as opposed to $\mathrm{NaCl}$ [9]. This practice was refined one year later by $\mathrm{Dr}$. Thomas Latta and his collaborators located in the Leith Cholera Hospital in Scotland as well as in other institutions in the UK, who initiated the practice of infusing massive amounts of saline solution, with resultant immediate recovery of intravascular volume and symptom improvement [10] (Fig. 1). According to Robert Lewins, "The most wonderful and satisfactory effect is the immediate consequence of the injection...The solution...consisted of two drachms of muriate, and two scruples of carbonate, of soda, to sixty ounces of water" [11]. Converting these apothecary weights and avoirdupois volume to their metric equivalents, the solution would be hypotonic at $185.2 \mathrm{mM}$ and also strongly alkaline, likely accounting for its good short-term results but poor long-term success. His remarkable discovery lit up the 
CASE 3.-A middle-aged man, of sober industrious habits, in whose family several cases of cholera had occurred, was, on the 27 th of May, at 9 p.m., seized with the first symptoms of that disease, and was subjected to the ordinary treatment for seven hours previous to his coming uuder my care. On the morning of the 28th, at half-past five, his countenance was pallid, his eyes sunk, his voice choleric in the highest degree; pulse 118, fluttering: every feature sharp ; extremities cold; had had saline injections per anum, laxatives, opiates, stimulants, hot applications, sinapisms, \&c. \&c., and notwithstanding he sunk rapidly, particularly during the bour previous to injecting the veins; an opera. tion which was unavoidably delayed, I being engaged with another patient. In half an hour eight pounds were injected with entire relief to every unpleasant feeling, if we except the irritation arising from the sinapism. Was ordered to take hourly small doses of calomel and opium, and beef. tea, enemata, with muriate of soda. Diarrhœa continued copious and frequent, and by 2 p.m. he seemed sinking fast; had almost lost his sight; recommenced the venous injection; scon his sight began to improve, and before a pound ras injected it was quite restored; about six pounds expelled all his uneasiness, and from that moment he continued to inprove, using only beeftea, mercurials, and effervescing draughts. Early next morning the stools became bilious, the secretion of urine was restored, and he was convalescent on the third day.

Fig. 1 Initial description by Thomas Latta of one of the first successful uses of intravenous saline for the treatment of intravascular volume depletion due to cholera (reproduced from [10] with permission)

"message boards" of journals such as The Lancet, which was flooded with multiple reports of cholera therapies. This extraordinary discovery would not come into widespread use until the early 20th century, when improved understanding of blood electrolyte composition, intravascular volume, and intravenous fluid delivery enabled its successful implementation [12], in particular by Leonard Rogers [13]. It was not until the 1940s, however, when the deeper understanding of blood electrolyte composition and whole body fluid and electrolyte dynamics enabled the safe and effective delivery of scientifically based intravenous fluid and electrolyte therapy [14-16] eventuating in the development of modern intravenous solutions (see [17] for a fascinating and detailed history). By 1957, numerous therapies had been proposed, as chronicled by Pollitzer, whose encyclopedic descriptions of therapies included serum, antibiotics [18, 19], bacteriophages, essential oils, and kaolin, before his lengthy description of infusion therapy [20]. Oral fluids, regarded mostly as palliative, were not considered to be first-line therapy at that time.

Over time, the public works projects aimed at improving the quality of drinking water and disposing of sewage combined with improvements in intravenous therapy brought an end to sporadic and pandemic cholera in the developed world. These changes, however, did not occur as rapidly in the developing world, in which cholera remains a major public health challenge.

This divergence was addressed by the next advance was the discovery by Robert Crane in 1960 (first published in full in 1962) that luminal sodium ions increased the rate of transport of glucose in rat ileum [21,22] work that was foundational for the study of ion cotransport mechanisms. This in turn was followed in 1968 by the publication of numerous studies conducted in India and Pakistan that reported that glucose-containing solutions perfused in the intestine via a long tube or consumed orally substantially decreased stool volume, documenting the efficacy of ORS in epidemic cholera. Since then, many publications have documented refinements of the original sodium-glucose-containing solution by adding organic components such as amino acids [23] or fermentable polymers such as resistant starch with further improvement on recovery times and treatment success [1,24-27]. At present, the main obstacles to the effective deployment of ORS therapy sadly arise mostly from societal and political, and not from medical barriers [28].

The studies of glucose cotransport were followed by the discovery and cloning of the $\mathrm{Na}^{+}$:glucose cotransporter SGLT1 by Ernest Wright followed by the cloning and characterization of cotransporters for many nutrients and ions, which has increased knowledge of fundamental membrane transport [29] and has also led to the development of SGLT2 inhibitors for diabetes [30, 31].

Along with ORS, research on cholera has also yielded valuable dividends in terms of the discovery of bacterial enterotoxins and their mechanism of action. The discovery of cholera exotoxin has been attributed to Dr. S. N. De, who reported in 1959 that sterile filtrates of Vibrio cholerce induced fluid secretion in; perfused rabbit jejunal loops [32, 33]. The next major basic scientific advance was the discovery in 1971 by Schafer et al. in 1970 [34] that cholera toxin increased intestinal cAMP levels, with publications in the following year by two groups at Harvard documenting that cholera toxin-induced adenylate cyclase to generate cAMP $[35,36]$, which provided the foundation for understanding the mechanism of exotoxin-induced intestinal fluid secretion. 
Table 1 The chronology of the major discoveries related to the pathogenesis and treatment of cholera

\begin{tabular}{|c|c|c|c|c|}
\hline Year & Discovery & Investigator & Paradigm shift & Clinical Translation \\
\hline Antiquity & First descriptions of cholera & & & \\
\hline 1817 & First global cholera pandemic & & & \\
\hline 1849 & $\begin{array}{l}\text { Transmission of cholera by con- } \\
\text { taminated water }\end{array}$ & John Snow & $\begin{array}{l}\text { Development of epidemiologic } \\
\text { methodology }\end{array}$ & Epidemiologic research \\
\hline 1854 & $\begin{array}{l}\text { Discovery of cholera microor- } \\
\text { ganisms }\end{array}$ & Filippo Pacini & $\begin{array}{l}\text { Bacterial basis of epidemic } \\
\text { diarrhea }\end{array}$ & $\begin{array}{l}\text { Prevention of waterborne infec- } \\
\text { tious diseases }\end{array}$ \\
\hline 1832 & $\begin{array}{l}\text { Intravenous hydration for severe } \\
\text { cholera }\end{array}$ & Thomas Lata and others & $\begin{array}{l}\text { Use of intravenous fluids for } \\
\text { cholera treatment }\end{array}$ & $\begin{array}{l}\text { Development of saline-based } \\
\text { solutions for intravascular } \\
\text { volume resuscitation }\end{array}$ \\
\hline 1886 & $\begin{array}{l}\text { Isolation and culture of Vibrio } \\
\text { cholerce }\end{array}$ & Robert Koch ${ }^{\mathrm{a}}$ & $\begin{array}{l}\text { Proving causality of infectious } \\
\text { agents in disease }\end{array}$ & $\begin{array}{l}\text { Foundations for the field of infec- } \\
\text { tious diseases }\end{array}$ \\
\hline 1959 & Discovery of cholera exotoxin & S. N. De & $\begin{array}{l}\text { Luminal action of cholera toxin, } \\
\text { discovery of enterotoxins }\end{array}$ & $\begin{array}{l}\text { GC-C receptor ligands for } \\
\text { functional bowel diseases and } \\
\text { constipation }\end{array}$ \\
\hline 1960 & $\begin{array}{l}\text { Discovery of } \mathrm{Na}^{+} \text {:glucose } \\
\text { cotransport }\end{array}$ & Robert Crane & $\begin{array}{l}\text { Discovery of ion cotransport as a } \\
\text { mechanism of active transport }\end{array}$ & $\begin{array}{l}\text { SGLT2 inhibitors, targeting drug } \\
\text { uptake }\end{array}$ \\
\hline 1968 & Development of ORS & David R. Nalin and others & $\begin{array}{l}\text { The efficacy of oral hydration for } \\
\text { massive fluid losses }\end{array}$ & $\begin{array}{l}\text { ORS and for epidemic diarrhea } \\
\text { and Pedialyte }{ }^{\circledR} \text { for pediatric } \\
\text { diarrhea }\end{array}$ \\
\hline 1971 & $\begin{array}{l}\text { Induction of adenylate cyclase by } \\
\text { cholera toxin }\end{array}$ & Michael Field and others & $\begin{array}{l}\text { The discovery of the mechanism } \\
\text { of toxin-induced fluid secretion }\end{array}$ & $\begin{array}{l}\text { GC-C receptor ligands for } \\
\text { functional bowel diseases and } \\
\text { constipation }\end{array}$ \\
\hline
\end{tabular}

${ }^{a}$ Recipient of the Nobel Prize for Physiology and Medicine in 1905 for studies related to M. tuberculosis

This line of investigation eventuated in the discovery that adenylate cyclase 6 is specifically induced by cholera toxin, providing a plausible target for translational studies [37, 38]. Another offshoot was the development of small molecule inhibitors of the cystic fibrosis transmembrane regulator (CFTR) anion channel that have been useful experimental tools but have not yet been translated into mainstream clinical use for toxigenic diarrhea $[39,40]$. Although the original hope was to find interventions that decreased fluid secretion, the discovery of the mechanism of action of cholera toxin has been translated into a class of drugs, the guanylate cyclase $\mathrm{C}$ (GC-C) receptor ligands, that effectively treat constipation in IBS patients by mimicking the closely related prosecretory actions of E. coli heat stable enterotoxin to produce in essence highly attenuated symptoms of cholera by inducing mucosal cGMP production [41]. These accomplishments are summarized in Table 1.

In this issue of Digestive Diseases and Sciences, two giants of cholera therapy with ORS have summarized the field and their contributions to this area. Dr. Henry Binder has spent most of his long and distinguished career as an academic clinician-investigator studying the mechanisms of intestinal ion and water secretion. Of his many important discoveries, he was the first to describe the advantages of the inclusion fermentable carbohydrate polymers in ORS [42]. Dr. Zulfiqar A. Bhutta, who has spent most of his professional career studying the barriers that have prevented the full deployment of ORS in the developing world, provides a first-hand account of how ORS therapy is sadly underused despite its unparalleled safety, efficacy, and low cost [43].

The two accompanying articles provide fascinating insight into the development of ORS and the many steps needed to promote its use in the developing world. I urge you to read these first-hand accounts of the development of what is considered to be "...potentially the most important medical advance this century" [44].

Acknowledgment The author thanks Prof. Ernest Wright for his helpful comments and suggestions.

\section{References}

1. Nalin DR, Cash RA. 50 years of oral rehydration therapy: the solution is still simple. Lancet. 2018;392:536-538.

2. Lippi D, Gotuzzo E, Caini S. Cholera. Microbiol Spectr. 2016;4.

3. Pollitzer R. Cholera studies 1 History of the disease. Bull World Health Organ. 1954;10:421-461.

4. Snow J. Cholera and the Water Supply in the South Districts of London in 1854. J Public Health Sanit Rev. 1856;2:239-257.

5. Snow J. On the Mode of Communication of Cholera. London: John Churchill, Soho; 1849.

6. Bentivoglio M, Pacini P. Filippo Pacini: a determined observer. Brain Res Bull. 1995;38:161-165. 
7. Pacini F. [Osservazioni microscopiche e deduzioni patologiche sul cholera asiatico] (Microscopic observations and pathological deductions on Asiatic cholera). Gazzetta Medica Italiana: Toscana $1854 ; 4: 397-401 ; 405-412$.

8. Koch R. Further Researches on Cholera. Br Med J. 1886;1:62-66.

9. O'Shaughnessy WB. Proposal of a new method of treating the blue epidemic cholera by the injection of highly-oxygenized salts into the venous system. Lancet. 1831;17:366-371.

10. Latta T. Letter from DR. LATTA of Leith, detailing Three Cases, of which one was successful. Lancet. 1832;18:370-373.

11. Lewins R. Injection of saline solutions in extraordinary quantities into the veins in cases of malignant cholera. Lancet. 1832;18:243.

12. Foëx BA. How the cholera epidemic of 1831 resulted in a new technique for fluid resuscitation. Emerg Med J. 2003;20:316-318.

13. Rogers L. The variations in the pressure and composition of the blood in cholera; and their bearing on the success of hypertonic saline transfusion in its treatment. Proc $R$ Soc B Biol Sci. 1909;81:291-302.

14. Marriott HL. Water and salt depletion. Br Med J. 1947;1:328-332.

15. Marriott HL. Water and salt depletion. Br Med J. 1947;1:285; passim.

16. Marriott HL. Water and salt depletion. Br Med J. 1947;1:245; passim.

17. Awad S, Allison SP, Lobo DN. The history of $0.9 \%$ saline. Clin Nutr. 2008;27:179-188.

18. Felsenfeld O, Soman DW. Treatment of cholera with antibiotics. Ann N Y Acad Sci. 1952;55:1059-1062.

19. Reimann HA, Chang GCT, Chu L-W, Ou Y. Asiatic choleraclinical study and experimental therapy with streptomycin. Am J Trop Med Hyg. 1946;s1-26:631-639.

20. Pollitzer R. Cholera studies. IX. Symptomatology, diagnosis, prognosis, and treatment. Bull World Health Organ. 1957;16:295-430.

21. Bihler I, Crane RK. Studies on the mechanism of intestinal absorption of sugars. V. The influence of several cations and anions on the active transport of sugars, in vitro, by various preparations of hamster small intestine. Biochim Biophys Acta. 1962;59:78-93.

22. Crane RK. The gradient hypothesis and other models of carriermediated active transport. Rev Physiol Biochem Pharmacol. 1977;78:99-159.

23. Nalin DR, Cash RA, Rahman M, Yunus M. Effect of glycine and glucose on sodium and water adsorption in patients with cholera. Gut. 1970;11:768-772.

24. Chaudhuri RN, Chakravarti RN, Neogy KN, Manji P. A composite rehydration fluid in treatment of cholera. J Indian Med Assoc. 1968;51:290-291.

25. Hirschhorn N, Kinzie JL, Sachar DB, et al. Decrease in net stool output in cholera during intestinal perfusion with glucose-containing solutions. $N$ Engl J Med. 1968;279:176-181.

26. Nalin DR, Cash RA, Islam R, Molla M, Phillips RA. Oral maintenance therapy for cholera in adults. Lancet. 1968;2:370-373.

27. Pierce NF, Banwell JG, Mitra RC, et al. Oral maintenance of water-electrolyte and acid-base balance in cholera: a preliminary report. Indian J Med Res. 1968;56:640-645.
28. Santosham M, Chandran A, Fitzwater S, Fischer-Walker C, Baqui $\mathrm{AH}$, Black R. Progress and barriers for the control of diarrhoeal disease. Lancet. 2010;376:63-67.

29. Wright EM, Turk E. The sodium/glucose cotransport family SLC5. Pflugers Arch. 2004;447:510-518.

30. Wright EM, Loo DD, Turk E, Hirayama BA. Sodium cotransporters. Curr Opin Cell Biol. 1996;8:468-473.

31. Rieg T, Vallon V. Development of SGLT1 and SGLT2 inhibitors. Diabetologia. 2018;61:2079-2086.

32. Cavalcante IC, Castro MV, Barreto AR, et al. Effect of novel A 2A adenosine receptor agonist ATL 313 on Clostridium difficile toxin A-induced murine ileal enteritis. Infect Immun. 2006;74:2606-2612.

33. Hall RH. A De in the life of cholera. Indian J Med Res. 2011;133:146-152.

34. Schafer DE, Lust WD, Sircar B, Goldberg ND. Elevated concentration of adenosine 3':5'-cyclic monophosphate in intestinal mucosa after treatment with cholera toxin. Proc Natl Acad Sci USA. 1970;67:851-856.

35. Sharp GW, Hynie S. Stimulation of intestinal adenyl cyclase by cholera toxin. Nature. 1971;229:266-269.

36. Kimberg DV, Field M, Johnson J, Henderson A, Gershon E. Stimulation of intestinal mucosal adenyl cyclase by cholera enterotoxin and prostaglandins. J Clin Invest. 1971;50:1218-1230.

37. Fenton RA, Murali SK, Kaji I, et al. Adenylyl cyclase 6 expression is essential for cholera toxin-induced diarrhea. J Infect Dis. 2019;220:1719-1728.

38. Thomas A, Ramananda Y, Mun K, Naren AP, Arora K. AC6 is the major adenylate cyclase forming a diarrheagenic protein complex with cystic fibrosis transmembrane conductance regulator in cholera. J Biol Chem. 2018;293:12949-12959.

39. Thompson KE, Ray RM, Alli S, et al. Prevention and treatment of secretory diarrhea by the lysophosphatidic acid analog Rx100. Exp Biol Med (Maywood). 2018;243:1056-1065.

40. Thiagarajah JR, Verkman AS. Chloride channel-targeted therapy for secretory diarrheas. Curr Opin Pharmacol. 2013;13:888-894.

41. Waldman SA, Camilleri M. Guanylate cyclase-C as a therapeutic target in gastrointestinal disorders. Gut. 2018;67:1543-1552.

42. Binder HJ. Development and pathophysiology of oral rehydration therapy for the treatment for diarrhea. Dig Dis Sci. (Epub ahead of print). https://doi.org/10.1007/s10620-019-05881-3.

43. Khan AM, Wright JE, Bhutta ZA. A half century of oral rehydration therapy in childhood gastroenteritis: toward increasing uptake and improving coverage. Dig Dis Sci. (Epub ahead of print). https ://doi.org/10.1007/s10620-019-05921-y.

44. Anonymous: Water with sugar and salt. Lancet 1978;2:300-301.

Publisher's Note Springer Nature remains neutral with regard to jurisdictional claims in published maps and institutional affiliations. 